Revista Iberoamericana, Vol. LXXVI, Núm. 230, Enero-Marzo 2010, 63-79

\title{
DO ESTIGMA À LIBERAÇÃO: REPRESENTAÇÕES DOS JUDEUS NA LITERATURA BRASILEIRA
}

\author{
POR \\ REgina ZiLBerman \\ Universidade Federal do Rio Grande do Sul
}

FREUD E OS JUDEUS

Ao redigir Moisés e o monoteísmo, Sigmund Freud (1856-1939) tinha como propósito entender porque os judeus, povo que remontaria ao segundo milênio antes de Cristo e que se dispersara geograficamente desde o primeiro século da era cristã, com a destruição do templo pelo imperador romano Tito (39-81), não perdera sua unidade e sobrevivera a muitos infortúnios. Sua intenção era igualmente entender as razões do anti-semitismo, isto é, porque os judeus continuavam a ser acusados e perseguidos em pleno século vinte, processo de que foi tanto testemunha, quanto vítima, já que a Áustria, país onde nasceu e viveu a maior parte de sua existência, aderiu, em 1938, ao Reich alemão e deu continuidade à política antijudaica propalada pelo nazismo, obrigando-o, velho e doente, a procurar abrigo na Inglaterra, onde faleceu.

Para chegar à compreensão do fenômeno político e ideológico que permanecia vivo à sua época, Freud usou a metodologia a que a prática psicanalítica o habituara: a busca dos eventos localizados na origem. No caso do anti-semitismo, que tinha o povo israelita como alvo, cabia retornar ao momento de fundação da religião judaica. Como a perspectiva de Freud é inteiramente desprovida de intuitos religiosos, já que o investigador se entende um cientista, e o indivíduo se declara ateu, ele descarta antecipadamente as explicações míticas e sagradas, os acontecimentos sobrenaturais, e os atos atribuídos à divindade. Interessam-lhe unicamente os dados históricos, encontrados nas pesquisas que procuram conferir veracidade a acontecimentos relatados na Bíblia e em outros documentos da Idade Antiga.

O objetivo de Moisés e o monoteísmo apresenta-se com clareza na terceira parte, denominada "Moisés, o seu povo e a religião monoteísta”, redigida quando Freud já se encontrava na Inglaterra. Antes disso, o autor expõe suas teses relativamente à figura de Moisés, antecipadas em dois artigos publicados em 1937, na revista Imago, em Viena, em que procura provar: 
a) a naturalidade egípcia de Moisés, contrariando o texto bíblico, segundo o qual o herói do Êxodo tinha ascendência hebraica;

b) a crença monoteísta de Moisés, seguidor do culto deAton, imposto, no século catorze a. C., pelo faraó Amenófis IV, depois denominado Aquenaton;

c) a aceitação do monoteísmo por parte de uma tribo semita, que, liderada por Moisés, deixa o Egito, na direção de Canaã;

d) o assassinato de Moisés por seus seguidores, que, depois, se aliam aos árabes madianitas, adoradores de Jeová, um deus vulcânico, bárbaro e violento;

e) o processo de transformação do culto de Jeová, ao serem absorvidos os ideais monoteístas e espiritualistas advogados por Moisés, praticados doravante pelos hebreus residentes em Canaã.

Essas teses resumem os acontecimentos primordiais da religião judaica, cuja base decorre da iniciativa de Moisés, impondo o monoteísmo a um grupo escolhido por ele, e cuja continuidade associa-se a um ato condenável, o assassinato do líder durante o percurso rumo a Canaã.

Segundo Freud, esse segundo acontecimento é o que efetivamente importa, pois o crime cometido é esquecido pelo grupo, que não o confessa, nem o admite. $\mathrm{O}$ reconhecimento dessa circunstância permite a Freud aplicar dois de seus conceitos mais estimados: o de latência, já que o fato encoberto continua a agir na interioridade do grupo; e o de retorno do reprimido, quando o trauma latente eclode, evidenciandose à consciência, de modo, porém, transformado. Assim, o crime suscita a culpa, e essa determina a valorização do ente vitimado pela transgressão. Contudo, o próprio crime permanece oculto, o que maximiza a culpa e, por extensão, seu objeto - no caso, a figura de Moisés, divinizado, e o monoteísmo, depurado de componentes sensuais e materiais, tal como é praticado pelo judaísmo.

A história de Moisés repete, em outro plano, o que acontece à horda primordial, conforme a tese de Freud em Totem e tabu (1970). O ponto de partida é o mito do assassinato de um pai primordial, a quem os filhos deviam obediência integral e que tinha acesso a todas as mulheres da tribo. Revoltados, os descendentes provocam a morte desse ser autoritário; ao mesmo tempo, estabelecem regras para impedir a repetição dos atos paternos - a proibição do incesto e da endogamia. Além disso, endeusam o pai assassinado sob a forma de um totem, a quem prestam culto, a quem temem, mas a quem tornam a devorar simbolicamente sob a forma de um ritual de purgação, periodicamente repetido.

O ritual totêmico esboça a protoforma da religião, calcada no respeito a um ser superior e ausente; e garante a ordem social, pois substitui a autoridade do pai pela obediência à lei. Sua base é o sentimento de culpa, compartilhado por todos, que cerceia a liberdade individual, separa indivíduos de gerações e gêneros diferentes, e afiança a coesão coletiva.

Revista Iberoamericana, Vol. LXXVI, Núm. 230, Enero-Marzo 2010, 63-79
ISSN 2154-4794 (Electrónico) 
O assassinato de Moisés corresponde a uma segunda etapa desse processo. Se a infração é similar, os resultados representam um acréscimo no que Freud chama o “progresso na direção da espiritualidade” (Freud, Moïse et le monothéisme 154) ou “os avanços em intelectualidade” (Freud, Moisés e o monoteísmo 100), já que, em lugar da presença física de um deus, concretizado pelo totem, emerge a concepção da divindade desprovida de materialidade e de representação icônica. Eis o que Freud considera a essência do judaísmo: uma religião monoteísta, que privilegia o intelecto, valoriza a repressão dos instintos e depende do sentimento de culpa experimentado por seus seguidores.

Freud lembra que a história da religião engloba ainda um terceiro episódio em que o sacrifício de um ente sagrado ocupa lugar fundador: o cristianismo. Só que Cristo é o filho, e não o pai, alteração que modifica o conteúdo do mito, pois é o primeiro que se deixa imolar em nome do segundo, a fim de libertar a humanidade de seus delitos. Por sua vez, o ato de purgação tem efeitos prospectivos, já que é válido para todos os que acompanharem o culto cristão. Uma clivagem se estabelece entre os que, como os judeus, carregam a culpa e sentem-se responsáveis por ela, de um lado; e, de outro, os cristãos, que expurgam aquele sentimento, não apenas por terem sido liberados pelo gesto do filho de Deus, mas também por terem a quem acusar. Reforça-se, por esse caminho, a culpabilidade dos judeus, alvos doravante da incriminação e da perseguição dos não-judeus.

Ao expor a tese final, Freud complementa o objetivo da obra dedicada ao homem Moisés e à religião monoteísta. Ao chegar a esse ponto, esclarece-se igualmente o processo como elabora seu raciocínio: o ponto de chegada era provavelmente conhecido do autor quando começou a explanar sua teoria a propósito da naturalidade de Moisés; contudo, ele não o evidenciou de imediato, atendo-se aos dados obtidos em obras sobre história do Egito, descobertas arqueológicas e exegese bíblica. Somente depois de se convencer da historicidade e veracidade dos fatos com que lida, interpreta-os à luz da teoria psicanalítica, a partir da qual pode entender as razões dos fenômenos que vitimam os judeus.

Embora conheça de antemão o ponto de chegada, ou ao menos suspeite dele, Freud desenvolve seu pensamento como se ignorasse onde vai dar. Eis porque seguidamente confessa suas inseguranças, ciente do caráter polêmico de sua tese e da fragilidade da maioria de suas evidências, impressões que estudiosos de sua obra não deixam de confirmar (Scliar, 1999; Bernstein, 2000). Mesmo assim, Freud não desiste de levar avante a tarefa, insistindo em suas premissas, que correspondem aos alicerces de uma construção, cujo plano geral não desconhece. O retorno ao começo não é, porém, mera estratégia retórica, pois o psicanalista procura mostrar-se coerente com a metodologia que criou, segundo a qual cabe retroceder aos começos para se compreender o estágio atual dos acontecimentos.

Revista Iberoamericana, Vol. LXXVI, Núm. 230, Enero-Marzo 2010, 63-79
ISSN 2154-4794 (Electrónico) 
Esse estágio corresponde à situação vivenciada pelo próprio autor, que se identifica como judeu, sofrendo, como seus compatriotas, as conseqüências do anti-semitismo, que o nazismo ajudou a difundir. Logo, o judeu de Freud é vítima, ainda que tenha internalizado a culpa, não um infrator que mereça punição. Ocorre que o judeu-vítima não incorre em representações, enquanto que o judeu-culpado é matéria de expressões tanto visuais como verbais, de teor negativo, ao apresentá-lo como herege, agiota ou maldito.

Freud não ignoraria essas figurações, que remontam à Idade Média. A imagem do ímpio, herege, pactário ou pária, merecedor de repulsa, dada a prática de atos condenáveis, aparece mesmo na literatura canônica, de que é exemplo a narrativa de Geoffrey Chaucer (c. 1343-1400), “The Prioress’s Tale” [O conto da prioresa], protagonizada pelo "cursed Jew" (Chaucer 114), o "judeu maldito", que, por maldade, mata um menino e joga seu cadáver em um poço, criança salva graças à interferência da Virgem Maria. Por sua vez, a do agiota, que empresta dinheiro a juros altos e que cobra sua dívida de modo implacável, é exemplificada por Shylock, de O mercador de Veneza, de William Shakespeare (1564-1616), de 1596. Semelhante a Shylock é Barrabás, de O judeu de Malta, tragédia de Christopher Marlowe (1564-1593), de 1590, definido por "suas bolsas", "cheias de dinheiro" (Marlowe 54), que, na primeira cena, aparece diante de "pilhas de ouro" (56) e que comenta, a propósito de seu povo: "a fortuna nos envolve por mar e por terra" (62), "enriquecendo-nos por um e por outro lado" (62).

Na acepção de Freud, a culpa importada da Antigüidade, resultante da morte criminosa de Moisés, de que sobrevieram as características peculiares do monoteísmo israelita, repercutiu sobre a condição do judeu na sociedade e explicou o comportamento adotado diante dele, preferentemente acusatório. Esse processo, porém, gerou emblemas que se entranharam na cultura e na arte do Ocidente, sinais físicos e atitudes típicas não examinadas por Freud, mas compreensíveis desde seu enfoque.

\section{JudEUS NO ROMANTISMO BRASILEIRO}

Não são judeus brasileiros os primeiros a introduzir personagens de origem hebraica em suas obras. Nem mesmo Antônio José da Silva (1705-1739), conhecido por O Judeu, inclui figuras ficcionais com as quais compartilharia a etnia. O mesmo se passa com Bento Teixeira (1561?-1618?), da Prosopopéia, eAmbrósio Fernandes Brandão, dos Diálogos das grandezas do Brasil, obras do século dezessete. João Mendes da Silva, pai de Antônio José da Silva e "nascido no Rio de Janeiro pelos anos de 1650 a 1660 e falecido em Lisboa em 1736”, conforme Joaquim Norberto (Silva 110), teria escrito Cristiados, poema em honra de Jesus Cristo, "só para que

Revista Iberoamericana, Vol. LXXVI, Núm. 230, Enero-Marzo 2010, 63-79
ISSN 2154-4794 (Electrónico) 
o não perseguissem”, segundo Varnhagen (Varnhagen 30), mas nada restou dessa obra. O filho não teve a mesma sorte, tendo sido condenado à morte pelo Tribunal do Santo Ofício, o poderoso instrumento da Inquisição, atuante em Portugal e suas colônias desde o século dezesseis. Embora a conversão dos judeus portugueses, por força de ato de D. Manuel I (1469-1521), datasse da primeira década do século dezesseis, duzentos anos depois pessoas ainda eram acusadas de práticas judaizantes. Sob tais circunstâncias, era pouco provável que escritores e intelectuais, vivendo em Portugal ou em suas colônias, se atrevessem a tratar de assuntos ainda que levemente associados aos israelitas.

Aconstituição brasileira de 1824 assegurou a liberdade de culto. Mas, no século dezenove, cristãos-novos remanescentes dificilmente se lembrariam de reavivar a religião dos antepassados; por sua vez, não se apresentaram novos contingentes de imigrantes, pois a perspectiva liberal de que, nesse aspecto, se revestia nossa constituição, coincidia com a tônica adotada na Europa ocidental, na esteira dos direitos alcançados pela revolução francesa e difundidos à época da expansão napoleônica. A Europa do século dezenove, ao menos em países como a França, a Inglaterra e a Alemanha, assistia ao abrandamento do anti-semitismo, de que é sintoma a relativa autonomia com que cientistas, pesquisadores e intelectuais como Freud e Karl Marx (1818-1883) puderam desenvolver e difundir suas idéias revolucionárias.

O expurgo ou a assimilação dos cristãos-novos, assim como a praticamente inexistente imigração de novos grupos de judeus, talvez explique porque nãojudeus sentem-se à vontade para incluir figuras pertencentes à etnia hebraica em suas obras. Essa presença se evidencia em Antônio José ou o poeta e a inquisição, tragédia encenada no Rio de Janeiro, em 1838, com que seu autor, Gonçalves de Magalhães (1811-1882), pretende inaugurar a dramaturgia nacional.

Em 1838, Magalhães já detinha posição de destaque na vida literária brasileira. Em 1836, ele publicara Suspiros poéticos e saudade, obra em que se reconhece, desde logo, sua adesão à estética romântica, em ascensão na Europa, mas ainda não praticada em terras brasileiras. Com Antônio José, o autor deseja alcançar efeito similar, conforme evidencia no prólogo à edição impressa da tragédia, de 1839: "Desejando encetar minha carreira dramática por um assunto nacional, nenhum me pareceu mais capaz de despertar as simpatias e as paixões trágicas do que este” (Magalhães, "Breve notícia” 7).

Entende-se porque Magalhães escolhe Antônio José para protagonizar o tema do artista perseguido: o poeta simbolizaria o escritor brasileiro que, abafado pelo poder metropolitano, não dispôs de oportunidade para desenvolver uma arte autóctone e nacional. A tese é exposta no "Ensaio sobre a história da literatura do Brasil”, publicado em 1836 na revista Niterói, quando Magalhães acusa Portugal

Revista Iberoamericana, Vol. LXXVI, Núm. 230, Enero-Marzo 2010, 63-79
ISSN 2154-4794 (Electrónico) 
por “o Brasil, descoberto em 1500, [ter jazido] três séculos esmagado debaixo da cadeira de ferro, em que se recostava um governador colonial com todo o peso de sua insuficiência, e de sua imbecilidade.” Por causa disso, "os melhores gênios em flor morriam, faltos deste orvalho protetor, que os desabrocha; um ferrete ignominioso de desaprovação, na fronte gravado do brasileiro, indigno o tornava de altos e civis empregos" (Magalhães, "Ensaio sobre a história da literatura do Brasil” 138-39).

Foi para encarnar a condição do gênio abortado que Magalhães convocou Antônio José, cuja origem judaica o poeta não ignora, referida no prólogo, bem como reiterada sucessivas ocasiões no decorrer do drama:

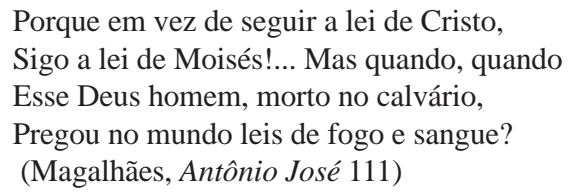

Magalhães, ao final do prólogo, destaca que sua obra é "a primeira tragédia escrita por um brasileiro, e única de assunto nacional” (Magalhães, "Breve notícia” 9), assunto esse corporificado por Antônio José, em decorrência de sua identidade particular, nascido no Brasil e judeu. Dessa maneira, o autor estabelece uma instigante analogia entre a condição de perseguido, experimentada pelo dramaturgo do século dezoito, e o artista nacional, como se apenas um judeu, por sua situação de estigmatizado e previamente criminalizado, pudesse expressar a marginalização do criador brasileiro no contexto da sociedade colonial policiada pela metrópole lusitana.

Na tragédia de Magalhães, a personagem de origem hebraica pertence ao sexo masculino e protagoniza uma tragédia. Na obra de Castro Alves (18471871), mudam-se os gêneros: são figuras femininas que se mostram nos versos de "Hebréia” e "Ester", textos de Espumas flutuantes. Os versos de "Hebréia” são dedicados a uma jovem que desperta a atenção do eu lírico, de um lado, por sua juventude e beleza, de outro, por sua etnia, conforme sugerem as linhas iniciais da segunda estrofe: "Tu és, ó filha de Israel formosa... / Tu és, ó linda, sedutora Hebréia...” (Alves 29).

Na terceira estrofe, o eu lírico questiona a palidez e a tristeza da moça, causadas talvez pela saudade de sua terra - "as infindas plagas, / Onde a oliveira no Jordão se inclina”, a "terra santa do Oriente imenso". Por sua vez, ele expõe seus sentimentos, de ordem amorosa, ao se comparar a Jacó, e de natureza erótica, ao mencionar o banho de Susana:

ISSN 0034-9631 (Impreso) 


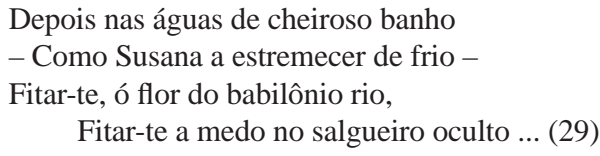

A natureza erótica da cena decorre da associação ao episódio em que dois anciãos, movidos pela "concupiscência” (Livro de Daniel 13) e de modo clandestino, assistem ao banho de Susana. A "hebréia” de Castro Alves sintetiza, por meio de suas alusões, de uma parte, à etnia da moça, de outra, à tradição bíblica, os elementos exóticos e eróticos que conformam a imagem da mulher judia.

No soneto "Ester", é enquanto oriental que a mulher judia é caracterizada:

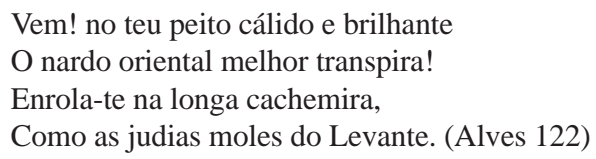

O poeta alude também à natureza "errante" do povo da "musa de Israel” que suscita seu canto, errância que a moça sumaria, pois o eu lírico não alcança retêla:

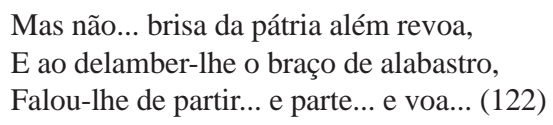

Em "Ester", o exotismo também se faz presente, decorrente do "orientalismo" (Saïd, 2007) de que a figura se reveste. O erotismo igualmente compõe a personagem, a que se acrescenta a caracterização de seu povo, disperso e, talvez por essa razão, inatingível pelo poeta, que vê a jovem escapar, restando dela tão-somente sinais impalpáveis, como "um perfume”, “um canto”, “um rastro” (Alves 123).

"Hebréia” e "Ester" talvez se refiram a uma mesma pessoa, pois estudiosos de Castro Alves sugerem ter o escritor mantido relações com uma moça de procedência israelita. A circunstância biográfica é relevante, porém não basta para explicar o modo como se compõe a imagem da jovem que suscita a atenção do sujeito lírico. Formam essa imagem:

- dados extraídos da tradição bíblica, que justificam as alusões a episódios da vida de Jacó (a devoção a Raquel; a luta com o anjo) e acontecimentos relatados no Livro de Daniel;

- dados sugeridos pela história, relativos à dispersão do povo judeu;

- fatores de ordem ideológica, que situam o judeu no âmbito do mundo oriental, daí decorrendo as principais comparações exploradas liricamente pelo poeta.

ISSN 0034-9631 (Impreso) 
Assim, a imagem construída por Castro Alves advém sobretudo das informações culturais obtidas pelo escritor, que determinam sua visão da mulher judia, independentemente de sua experiência pessoal. Dentre essas informações, predominam as que privilegiam o exotismo, situação que libera o autor para a exploração dos fatores eróticos despertados pela jovem hebréia, ainda que o sujeito lírico não avance para além das insinuações do desejo, evidenciadas pela associação ao episódio de Susana, em "Hebréia”, e pelas lembranças que “Ester” lega ao texto do poeta.

Gonçalves de Magalhães, em seu drama, explora o que a condição do judeu tem de alegórica, habilitando Antônio José ao papel de herói e ao desempenho da função trágica. Em lugar dos nefastos Shylock e Barrabás, avulta o bom caráter do protagonista, que, à hora da morte, ainda perdoa seu acusador, agora arrependido. Assim, Gonçalves de Magalhães vale-se simultaneamente do fato histórico - o auto-de-fé em que morreu Antônio José da Silva, dramaturgo nascido no Brasil que, em Lisboa, alcançou grande sucesso entre o público de comédias - e de uma imagem consolidada do judeu enquanto o perseguido em decorrência de sua origem étnica.

Além disso, o brasileiro dá voz a esse indivíduo conduzido à morte em virtude de sua procedência, o que o leva a questionar suas causas, já que, no contexto desenhado na tragédia, o flagelo de que é alvo o protagonista decorre das más intenções do acusador, o frei apaixonado por sua amada; por sua vez, os motivos da Inquisição enquanto processo político e religioso não se justificam, pois contradizem os princípios éticos do cristianismo original, conforme expõe o herói em um de seus solilóquios, antes citado. Embora não tenha escrito O poeta e a inquisição para discutir a questão judaica em qualquer uma de suas facetas, Magalhães acaba por estabelecer um marco, por reabilitar tanto uma figura histórica - o dramaturgo Antônio José, cuja obra, até os anos 30 do século dezenove, quando a tragédia foi redigida, não era valorizada (Denis, 1823; Garrett, 1998) - quanto um tipo de personagem, seguidamente jogado para a posição de antagonista ou de vilão, como em $O$ mercador de Veneza, de Shakespeare, ou em O judeu de Malta, de Marlowe.

Entre a obra de Magalhães e a de Castro Alves, passam-se mais de trinta anos. Nesse ínterim, o Romantismo adentrou-se na cultura brasileira, trazendo consigo vultos e obras em que o "orientalismo" se expande enquanto representação da sensualidade, da volúpia, do geográfica e historicamente remoto, e do não-cristão. O poeta baiano incorpora alguns desses traços, ao definir a figura feminina que desperta seu desejo; e, ainda que se reconheça algum recato na descrição dos traços da hebréia, a lubricidade se mostra na associação estabelecida com Suzana, personagem do Livro de Daniel. Contudo, o escritor não rejeita a atração sexual,

Revista Iberoamericana, Vol. LXXVI, Núm. 230, Enero-Marzo 2010, 63-79
ISSN 2154-4794 (Electrónico) 
mas a valoriza, descriminalizando a pessoa que a suscita; além disso, tal como a bíblica Suzana, a hebréia não almeja seduzir seu admirador, cujo apreço manifestase exclusivamente por meio dos versos do poema. Também a "Ester" afasta-se de seu cantor, voltando-se na direção de sua "pátria", que "além revoa".

Ainda que não dê voz à personagem, o poeta considera-a sua "musa" e conferelhe o poder de exprimir "os martírios" de um "povo errante". Dirigindo-se a ela em segunda pessoa, Castro Alves aproxima-se da figura feminina, sem deixar de elevá-la e valorizá-la a cada passo de qualquer dos dois poemas. Assim, a falta de voz não rebaixa a personagem de procedência judaica, mesmo porque ela é capaz de exprimir seu canto, alçando-se acima de seu admirador, que se rende a seu fascínio, sem perder o respeito pela mulher.

Também Castro Alves não deseja discutir a questão judaica; mas seus poemas revelam, pelo avesso, a dualidade experimentada pelos membros da comunidade hebraica e apontada por Freud em Moisés e o monoteísmo, decorrente, de um lado, da permanência de sua condição, de outro, da dispersão e mobilidade do grupo, transitoriedade expressa em "Ester”. O poeta percebe o problema desde a perspectiva do apaixonado que perde a mulher amada, por mais que lhe devote sincero sentimento amoroso.

Também a fiç̧ão romântica incluiu personagens de extração hebraica, destacando-se, dentre os gêneros narrativos, o romance histórico, tal como o praticou Walter Scott (1771-1832). José de Alencar (1829-1877) foi um dos seguidores brasileiros do escritor escocês, sendo As minas de prata (1865) uma de suas obras mais bem acabadas. Redigido originalmente para dar continuidade a $O$ guarani (1857), paradigma da ficção indianista nacional, aquele romance tomou rumo independente, de que são testemunhas sua intriga e suas personagens.

O romance, transcorrido em 1609, é protagonizado por Estácio Correia, que almeja chegar às minas de prata tanto para reabilitar a memória de seu pai, Robério Dias, descobridor do local, mas julgado renegado e traidor pelo poder metropolitano, quanto para casar com sua amada, Inezita de Aguilar, pertencente a rica família de origem espanhola. O principal opositor do rapaz é Gusmão de Molina, jesuíta que deseja se apropriar das minas, visando fortalecer financeiramente a Companhia de Jesus e habilitar-se a posições mais elevadas na sua corporação. Ao final, Estácio descobre que as minas não abrigavam o desejado tesouro; mas desposa Inezita, após rocambolesca simulação de morte por parte dos amantes, à moda consagrada por Romeu e Julieta, de William Shakespeare.

A intriga principal não depende da ação de personagens de procedência hebraica. Uma trama paralela envolve, porém, o amigo de Estácio, Cristóvão Garcia D’Ávila, que ama, e é correspondido, Elvira de Paiva, filha da convertida e agora beata Luíza de Paiva, que deseja consagrar a jovem à vida religiosa. Uma segunda

Revista Iberoamericana, Vol. LXXVI, Núm. 230, Enero-Marzo 2010, 63-79
ISSN 2154-4794 (Electrónico) 
trama paralela conta com outras personagens judias: o agiota Samuel Levi e sua filha, Raquel, a quem se vincula o taberneiro Brás Judengo, figura híbrida que se une a qualquer indivíduo que queira comprar seus serviços, a maioria desses de tendência criminosa. Samuel Levi e Raquel, por sua vez, pertencem a uma indefinida comunidade de judeus, que se reúne em momento crucial da narrativa, para libertar prisioneiros holandeses e, com a ajuda deles, retornar à Europa.

Os dois grupos de judeus - de um lado, Luíza de Paiva e sua filha, Elvira; de outro, Samuel Levi e sua filha, Raquel - não chegam a se cruzar, embora a ação se passe principalmente na cidade de Salvador. Caso se encontrassem, provavelmente não se reconheceriam, pois Luiza de Paiva deseja apagar seus traços judaicos, ainda que, em dado momento da intriga, ela se lembre deles, enquanto que Samuel e Raquel almejam levar avante seu culto longe da ameaça de perseguição e dissolução religiosa.

Relativamente aos problemas experimentados por Samuel e pelos demais judeus da intriga, Alencar é bastante meticuloso, explicando os eventos da época, incluindo a hipótese de revogação da licença que permitia sua saída do reino de Portugal e que prometia não renovar a proibição em contrário. Essa hipótese, que pairava sobre os judeus da colônia, justificaria sua adesão ao partido da Holanda, nação que respeitaria o exercício de sua religião:

Os judeus da cidade do Salvador, como os de todo o Brasil, ameaçados da revogação da lei de 30 de junho de 1601, que lhes permitiu a passagem à colônia, apesar de a haverem comprado por 200.000 cruzados, faziam votos pela continuação da guerra e alimentavam a secreta esperança de ver o Estado do Brasil passar ao domínio da Holanda, a quem na falta da língua e da origem, os ligava o santo e poderoso vínculo da religião. (Alencar 572)

Assim, aquelas personagem decidem colaborar com os holandeses, inimigos da Espanha, logo, do Brasil, pois, sob sua bandeira, disporiam de liberdade. Eis o plano que nutre parte da ação da narrativa: Estácio impede que Samuel e seus companheiros ajudem os adversários dos ibéricos; por outro lado, coopera para que o idoso e sua filha possam retornar para o Velho Continente.

Alencar parece ter introduzido esse segundo grupo de atores para completar o enquadramento histórico, pois, em 1609, o Brasil fazia parte do império espanhol, que submetera Portugal em 1580 e que se opunha aos Países Baixos, os quais lutavam por sua independência. Mas o escritor não se restringe ao pano de fundo, já que o episódio permite evidenciar as qualidades militares de Estácio, além de pôr à prova seu amor por Inezita, ao não se render aos encantos de Raquel, discreta e persistente apaixonada do moço.

ISSN 0034-9631 (Impreso) 
A presença do par de personagens israelitas também põe à prova as simpatias de Alencar. De uma parte, Samuel carrega os traços negativos atribuídos ao judeu desde a Idade Média: é agiota, avarento e desconfiável, já que faz um pacto com os holandeses, futuros invasores da colônia americana; além disso, é um apátrida, pois define-o a pertença à etnia judaica, e não a uma nacionalidade qualquer. De outra, o narrador apresenta as razões do comportamento dessas personagens, consciente de que seus atos decorrem de sua necessidade de sobrevivência, razão pela qual não os condena. Raquel, por sua vez, coincide, em certo sentido, com a "Hebréia" de Castro Alves, já que traz marcas orientais em sua fisionomia e em suas atitudes. E conta com a compreensão do narrador, mesmo quando se submete à chantagem de José de Aguilar, que quer seduzi-la em troca da senha que libertará os holandeses, aliados da família Levi. Ao apaixonar-se por Estácio, mantendo-se, porém, à distância do rapaz e colaborando com a concretização de seus intuitos, Raquel acaba por conquistar definitivamente a simpatia da obra e, por extensão, a do leitor.

Não apenas diante das personagens hebréias assume Alencar atitude contemporizadora, já que Gusmão de Molina, o frade fanático que comete atos vis na tentativa de obter o tesouro legado a Estácio, além de prejudicar outras criaturas ficcionais, não é inteiramente condenado na obra. Ao contrário de O guarani, em que o jesuíta renegado Loredano tem conduta reprovável do início ao final da narrativa, Molina, em As minas de prata, ajuda Estácio, embora com segundas intenções, e morre nos braços da mulher que o ama, circunstância que, no contexto da poética romântica, atenua a avaliação dos delitos perpetrados.

Não surpreende, pois, que Alencar mostre-se leniente diante dos judeus, sobretudo quando se trata de personagens femininas. Elvira Paiva, por exemplo, alcança realização amorosa, desposando seu amado Cristóvão, o que legitima a criança gerada antes do casamento. Comportamentos transgressivos, como o dessa moça, são, pois, relegados a um segundo plano. Por sua vez, o procedimento de Raquel é invariavelmente exemplar, seja por defender a honra e a vida do pai a qualquer preço, seja por reconhecer a distância que a separa de Estácio, evitando, assim, qualquer ato censurável.

É que, no conjunto, As minas de prata constituem um livro conciliador, já que o próprio herói, Estácio, émestiço, descendente de Diogo Alvares Correia, o Caramuru, portanto, também da índia Paraguaçu. Dada sua origem, o pai de Inezita não aceita o casamento da filha com o brasileiro. Mas o matrimônio misto se consuma, ainda que de modo mirabolante, assim como Cristóvão, cristão-velho e nobre de estirpe, desposa Elvira Paiva, a cristã-nova e herdeira de rico mercador judeu. Além disso, mulatos, indígenas aculturados e populares de modo geral povoam a narrativa, multiplicando o número de personagens que, na maioria, tomam o partido de Estácio.

Revista Iberoamericana, Vol. LXXVI, Núm. 230, Enero-Marzo 2010, 63-79
ISSN 2154-4794 (Electrónico) 
Diante dos judeus, sejam os integrados à vida da colônia e que permanecem na Bahia, sejam os que lutam por sua sobrevivência e precisam retornar à Europa, o romancista toma atitude similar, oscilando entre a compreensão dos motivos e a exposição de preconceitos entranhados na representação dos judeus.

Esses aparecem sobretudo quando o narrador refere-se a Samuel, credor de importantes nomes da nobreza local. Seu apreço ao dinheiro revela-se em mais de uma cena, o que, porém, não o impede de procurar comprar a liberdade dos seus, a qualquer custo e com desprendimento. Assim, Samuel coincide e não coincide com a imagem européia do agiota insaciável de que Shylock, de O mercador de Veneza, é o representante canônico. No contexto do "lado de baixo do Equador", essas imagens se abrandam e desfazem-se, provavelmente porque correspondem a uma herança cultural adquirida, e não a uma experiência imediata.

Por sua vez, As minas de prata não desmentem o diagnóstico de Freud: Samuel e Raquel, sintetizando o grupo a que pertencem e que aparece em cena fugaz do livro, são criaturas apátridas, que dependem da benevolência de quem os acolhe, benevolência que nem sempre esconde segundas intenções que, cedo ou tarde, se evidenciam. Por isso, são também figuras em permanente trânsito, decorrendo de fatores transitórios e instáveis de seu percurso no mundo a continuidade e identidade de sua cultura e religião.

Os românticos brasileiros não desmentem as imagens com que os judeus são representados no Ocidente desde passado remoto; contudo, não as empregam para consolidar preconceitos, mas para desenvolver os temas de que se compõem suas obras. Em Gonçalves de Magalhães, o judeu ocupa lugar central e, ao mesmo tempo, metafórico; em Castro Alves, a mulher judia expressa a sensualidade do estranho e do exótico, que seduz o poeta, mas a qual ele não alcança conquistar.

José de Alencar, por sua vez, lida de modo mais complexo com personagens de procedência hebraica, até porque aumenta o número de participantes em sua trama. Algumas exercem posição mais central, como Elvira Paiva, outras são periféricas, como Raquel. Além disso, interpõe personagens masculinas, como Samuel Levi, cuja importância não advém do impulso que dá à trama, mas dos contrastes que lhe cabe explicitar - de um lado, com o cobiçoso Molina, confronto que o beneficia, pois sua ambição não é tão mal-intencionada; de outro, com o generoso Vaz Caminha, pai adotivo de Estácio, confronto que faculta entender as razões que levam um idoso a colaborar com o sucesso e a felicidade de um jovem, independentemente de sua coloração étnica.

O romancista, tal como seus pares românticos, não deseja discutir o problema dos judeus, menos ainda polemizar representações. Vale-se delas para estabelecer a estrutura do romance, sobretudo a organização do quadro de personagens, mesmo quando a participação desses no enredo é secundária. Não que a intriga não importe

Theroamericana, Vol, LXXVI, Núm, 230, Enero-Marzo-2010,63-79 ISSN 0034-9631 (Impreso) ISSN 2154-4794 (Electrónico) 
para o autor de As minas de prata, obra em que os eventos são trabalhados em várias frentes ao mesmo tempo; contudo, Alencar depende da funcionalidade dos atores, razão porque procura ordená-los por contrastes e semelhanças, valendo-se então dos traços étnicos para estabelecer as relações entre eles, incluindo nesse organograma os judeus.

Considerando as necessidades da narrativa em termos de fabulação e personagens, Alencar não podia abrir mão das imagens com que os judeus vinham sendo traduzidos pela tradição literária. Contudo, não as endossa, nem as contesta, utilizando-as na medida em que a trama requer. Pela mesma razão, não questiona suas causas, matéria que veio a preocupar Freud, cuja tese deixa, porém, uma pergunta em aberto, respondida pelo romance de Moacyr Scliar.

\section{EPISÓDIO FUNDADOR}

As personagens de procedência hebraica presentes nas obras dos escritores românticos relacionam-se, direta ou indiretamente, às representações constituídas e consolidadas pela cultura ocidental, transmitidas, em grande parte, pela literatura, incluindo-se aí autores e textos canônicos. Quando escritores judeus começam a atuar no sistema literário brasileiro, não adotam tais imagens, por essas serem exteriores a eles. Vivenciando internamente a questão judaica, não assumem estereótipos, a não ser para desconstruí-los. Dessa maneira, o problema identificado por Freud em Moisés e o monoteísmo, relativo à culpa e à perseguição, é examinado segundo o ângulo de suas conseqüências - a imigração, o holocausto, a assimilação, a resistência, temas que aparecem em narrativas de Marcos Iolovitch (1907-1984), Samuel Rawet (1929-1984), Moacyr Scliar (1937) e Clarice Lispector (1920-1977), por exemplo -, não, porém, desde a perspectiva de seus motivos ou de sua gênese.

Sob esse aspecto, cabe destacar o romance de Moacyr Scliar, Os vendilhões do templo (2006), porque essa obra relata o evento a ser considerado o mito de origem que tem como matéria a imagem negativa do judeu, aquela em que a culpa é designada não pelos próprios membros da coletividade hebraica, mas pelos que podem condená-los. Se Freud identifica as razões que explicam a unidade do povo judeu, cuja identidade resiste à dispersão, e a ótica incriminatória com que ele mesmo se entende, ótica absorvida e difundida pelos não-judeus, Scliar localiza o fato que legitimou, para quem a pratica, a acusação que se pereniza no tempo.

O romance consta de três partes, protagonizada a primeira pelo indivíduo cuja mesa Jesus teria derrubado, ao expulsar os mercadores instalados no templo, e que ouvira a denúncia do profeta, reproduzida em Mateus 21, 13: "Está escrito: Minha casa é uma casa de oração, mas vós fizestes dela um covil de ladrões!”. A personagem é designada tão-somente por seu trabalho - vendilhão -, embora

\footnotetext{
Revista Iberoamericana, Vol. LXXVI, Núm. 230, Enero-Marzo 2010, 63-79
ISSN 2154-4794 (Electrónico)
} 
tenha chegado a essa profissão, após ter migrado do campo para Jerusalém, em decorrência do empobrecimento da economia rural.

A trajetória do vendilhão desenvolve-se em três etapas: a primeira dá conta da decisão de mudar-se para Jerusalém, acompanhado pela mulher e os dois filhos; encontra trabalho no templo, onde vende com bastante sucesso suas pombas e ganha dinheiro; tem planos de prosperidade e deseja encontrar serviço para os rapazes, mas esses não acompanham seus projetos. A segunda etapa corresponde ao momento em que o Pregador ou Mestre, substantivos que designam Jesus, invade o templo e derruba a mesa do vendilhão, o que o deixa perplexo. Logo se dá conta de que o estado da cidade e de sua família alterou-se profundamente, perdendo ele o controle sobre os acontecimentos. Procura entender o que fazem os filhos e o que o Pregador significa; acompanha à distância a crucificação, mas não avalia seus efeitos. A fase final da narrativa apresenta sua tentativa de recuperar a unidade de sua família, consciente de que a situação anterior não mais poderia ser recomposta.

Na figura do vendilhão, agrupam-se dois processos: de um lado, a corrupção religiosa e política de que os sacerdotes administradores do templo constituem a expressão mais completa, o pragmatismo que vende salvação ou purificação aos necessitados, a opção dos judeus pelo comércio, na falta de outra alternativa profissional, dada a decadência das atividades rurais a que estavam habituados; de outro, a humanização da personagem, cuja individuação advém de suas expectativas e dificuldades pessoais: os problemas de relacionamento com os filhos, a necessidade de sobrevivência, a insegurança por se ver acossado pela prepotência dos poderosos, sejam os invasores romanos, que conquistaram suas terras, violentaram sua esposa e obrigaram-no a abandonar o lugar de nascimento, sejam os sacerdotes, que o ameaçam permanentemente.

O vendilhão, ainda que anônimo, é uma personagem problemática, na melhor tradição do romance psicológico, fazendo-o carregar uma dualidade permanente, entre o estereótipo a que corresponde e a pessoa que ele é. Por sua vez, ele só se torna um estereótipo após um acontecimento fundador - a invasão do templo pelo Pregador - e uma denúncia radical - a de que aquele espaço sagrado fora transformado em “covil de ladrões”. Antes disso, ele era apenas um comerciante bem sucedido, apesar da nostalgia da vida agrícola; depois do encontro com o Pregador Jesus, ele se metamorfoseia naquilo que se diz dele, embora tenha procurado fugir a esse resultado.

Esse malogro aparece em dois incidentes em que se introduzem no romance trechos extraídos das narrativas contidas nos evangelhos de São Mateus, São Marcos e São Lucas, bem como no corpo de lendas associadas à vida de Cristo. No primeiro deles, defrontam-se novamente o vendilhão e Jesus, que solicita ao comerciante, e depois joga no chão, a moeda com a efígie de César. Recusada a

Revista Iberoamericana, Vol. LXXVI, Núm. 230, Enero-Marzo 2010, 63-79
ISSN 2154-4794 (Electrónico) 
moeda pelo Pregador, o vendilhão hesita, mas não deixa de recolhê-la, configurando sua dificuldade para livrar-se da materialidade do dinheiro. No segundo, ocorrido após a crucificação, o protagonista depara-se com o judeu errante, Ahsverus, que profetiza o destino do vendilhão - "Tu serás visto como figura desprezível, a imagem da ganância”, "o teu vender e o teu comprar serão sempre lembrados com repulsa”, “aparecerás como uma figura abominável”(Scliar 134)-em conseqüência do episódio fundador:

É tua sina, uma sina traçada no momento em que encontraste o Crucificado. Naquele instante te tornaste o vendilhão do Templo. Tu antes eras apenas o homem que ficava atrás da mesa na qual estavam pombos e moedas. ... Ao virar essa mesa, ele subverteu o teu pequeno mundo, nele instaurando o caos - no qual tu, tuas moedas e teus pombos confundiram-se. (Scliar 135)

Do vendilhão para o judeu errante sintetiza-se o destino de um povo: de uma parte, a forma primordial do capitalista, indivíduo pragmático e destituído de ética, já que mesmo a religião pode ser vendida; de outro, o motivo para a dispersão, resumida na atitude do sapateiro que, ao desrespeitar o crucificado, foi condenado a vagar, sem descanso, pelo mundo, até o final dos tempos.

O vendilhão, de alguma maneira, busca escapar a seu destino, mesmo antes de conhecê-lo, situação encenada em momento anterior do romance, quando o protagonista ainda ignora a crucificação de seu antagonista no templo. Perplexo diante dos acontecimentos, mas procurando preservar a unidade de sua família, ameaçada de desfazer-se em razão da revolta dos filhos e da opressão do exército romano, o vendilhão celebra o ritual da Páscoa. Ao relembrar "a escravidão de seus antepassados, o êxodo do Egito", o protagonista "tinha esperança de que um milagre ocorresse naquela noite, um milagre semelhante ao que libertara os servos de seu cativeiro" (119):

Ele esperava que naquela noite todas as penosas lembranças - as privações do passado, as brigas com os filhos, a humilhação que o Pregador lhe infligira no pátio do Templo - desaparecessem como por encanto, e que eles pudessem, enfim, viver felizes. (Scliar 119)

O milagre não acontece, mas o seu contrário, sumariado na previsão do judeu errante, manifestada poucas páginas depois. Bastou, porém, para evidenciar a outra passagem, não mais a da liberação, liderada por Moisés, mas a da permanente opressão, marca da Páscoa cristã que, se culmina na ressurreição do Cristo, supõe a condenação dos que não seguiram a lição do Pregador.

$\begin{array}{lllll}\text { Revista Iberoamericana, Vol. LXXVI, Núm. 230, Enero-Marzo 2010, } & \text { 63-79 } \\ \text { ISSN 0034-9631 (Impreso) }\end{array}$ 
Scliar, por meio de seu romance, complementa a teoria de Freud, ao retomar o mito a partir do qual o psicanalista construiu sua tese sobre o monoteísmo ocidental. Primeiramente, porque acrescenta, ao episódio que alicerça a religião judaica, a narrativa que funda a representação do judeu como condenado - de um lado, a perpétua errância, de outro, a exclusão da salvação divina - compondo, assim, um díptico a partir do qual se escreve a história hebraica. Em segundo lugar, porque propõe outra interpretação para a figura de Moisés, não o precursor do Pregador, conforme Freud o entende, mas seu avesso, aquele que pode liberar os judeus sem que seja necessária qualquer renúncia, seja à própria tradição judaica, seja à vida terrena e material, como, em ambos os casos, tem em vista o Cristianismo.

O romance de Scliar, Os vendilhões do Templo, resgata uma representação, ajuda a compreendê-la e colabora para a liberação não apenas de preconceitos arraigados, mas das pessoas que, algozes ou vítimas deles, são, nas duas situações, seus prisioneiros.

\section{OBRAS CITADAS}

Alencar, José de. As minas de prata. Obra completa. Vol. II. Rio de Janeiro: Aguilar, 1964.

Alves, Castro. Poesias completas. Rio de Janeiro: Tecnoprint, s. d.

Bernstein, Richard J. Freud e o legado de Moisés. Laura Rumchinsky, trad. Rio de Janeiro: Imago, 2000.

Chaucer, Geoffrey. The Canterbury Tales. London: Panther, 1965.

Denis, Ferdinand. "Notice sur le théatre portugais". Chefs d'œuvre du théâtre portugais. [Paris]: Ladvocat, 1823. 2-28.

Freud, Sigmund. Tótem y tabú. Luis Lópes-Ballesteros y de Torres, trad. 4. ed. Madrid: Alianza, 1970.

Moïse et le monothéisme. Anne Berman, trad. Paris: Gallimard, 1980.

Moisés e o monoteísmo. Maria Aparecida Moraes Rego, trad. Rio de Janeiro: Imago, 2001.

Garrett, Almeida. "Bosquejo da história da poesia e língua portuguesa”. O berço do cânone. Regina Zilberman e Maria Eunice Moreira, orgs. Porto Alegre: Mercado Aberto, 1998. 29-73.

Livro de Daniel, 13. Em: < http://www.bibliacatolica.com.br/01/34/13.php> (acessado em 19 de fevereiro de 2008).

Magalhães, Gonçalves de. Antônio José ou o poeta e a inquisição. Tragédias. São Paulo: Martins Fontes, 2005.

“Breve notícia sobre Antônio José da Silva”. Tragédias. São Paulo: Martins Fontes, 2005. 5-9.

Revista Iberoamericana, Vol. LXXVI, Núm. 230, Enero-Marzo 2010, 63-79
ISSN 2154-4794 (Electrónico) 
“Ensaio sobre a história da literatura do Brasil”. Niterói. Revista Brasiliense 1. 1. Ed. facsimilada. São Paulo: Academia Paulista de Letras, 1978. 132-59.

Marlowe, Christopher. El judío de Malta. Eduardo II. 1592. Julio César Santoyo, trad. Madrid: Cátedra, 2003.

Mateus, 21. <http://www.bibliacatolica.com.br/01/47/21.php> (acessado em 23 de fevereiro de 2008).

Saïd, Edward. Orientalismo. Rosaura Eichenberg, trad. São Paulo: Companhia das Letras, 2007.

Scliar, Moacyr. Os vendilhões do templo. São Paulo: Companhia das Letras, 2006.

“Da Bíblia à psicanálise: saúde, doença e medicina na cultura judaica”. Diss. Fundação Oswaldo Cruz, Escola Nacional de Saúde Pública, 1999.

Silva, Joaquim Norberto de Sousa. "Bosquejo da história da poesia brasileira”. O berço do cânone. Regina Zilberman e Maria Eunice Moreira, orgs. Porto Alegre: Mercado Aberto, 1998. 100-42.

Varnhagen, Francisco Adolfo. “Ensaio histórico sobre as letras no Brasil”. Florilégio da poesia brasileira. Rio de Janeiro: Academia Brasileira, 1946. 3-58.

Revista Iberoamericana, Vol. LXXVI, Núm. 230, Enero-Marzo 2010, 63-79
ISSN 2154-4794 (Electrónico) 
